\title{
PEMBELAJARAN BAHASA INDONESIA DAN SASTRA (BASASTRA) DI SEKOLAH DASAR
}

\author{
Muhammad Ali \\ Univ. PGRI Palembang \\ Email : m.aliakila@gmail.com
}

\begin{abstract}
Abstrak:Pembelajaran bahasa Indonesia pada hakikatnya adalah membelajarkan peserta didik tentang keterampilan berbahasa Indonesia yang baik dan benar sesuai tujuan dan fungsinya. Mata pelajaran Bahasa Indonesia bertujuan agar peserta didik memiliki kemampuan berkomunikasi secara efektif dan efisien sesuai dengan etika yang berlaku, baik secara lisan maupun tulis, menghargai dan bangga menggunakan bahasaIndonesia sebagai bahasa persatuan dan bahasa negara, memahami bahasa Indonesia dan menggunakannya dengan tepat dan kreatif untuk berbagai tujuan, menggunakan bahasa Indonesia untuk meningkatkan kemampuan intelektual, serta kematangan emosional dan sosial, menikmati dan memanfaatkan karya sastra untuk memperluas wawasan, budi pekerti, serta meningkatkan pengetahuan dan kemampuan berbahasa, dan menghargai dan membanggakan sastra Indonesia sebagai khazanah budaya dan intelektual manusia Indonesia.
\end{abstract}

Kata kunci: Pembelajaran Bahasa Indonesia, keterampilan berbahasa Indonesia

\section{PENDAHULUAN}

Pendidikan pada dasarnya tidak dapat dipisahkan dalam kehidupan manusia. Karena dengan adanya pendidikan manusia akan mendapatkan ilmu pengetahuan. Pendidikan merupakan salah satu hal yang paling penting dalam segi pengetahuan bangsa Indonesia untuk menciptakan insan yang berilmu dan berwawasan sehingga meningkatkan kualitas sumber daya manusia yang cerdas.

Bahasa Indonesia di SD merupakan salah satu mata pelajaran yang dapat digunakan untuk mengembangkan aktivitas siswa. Bahasa merupakan alat komunikasi. Belajar bahasa berarti belajar berkomunikasi. Pembelajaran Bahasa Indonesia sendiri memiliki tujuan yang tidak berbeda dengan tujuan pembelajaran yang lain, yakni untuk memperoleh pengetahuan, keterampilan, kreativitas, dan sikap. Keterampilan berbahasa dalam kurikulum di sekolah mencakup empat aspek, yaitu: keterampilan menyimak (listening skills), keterampilan berbicara (speaking skills), keterampilan membaca (reading skills), keterampilan menulis (writing skills).

$$
\text { Dalam pembelajaran tugas }
$$
pendidik yang paling utama adalah mengkondisikan lingkungan belajar agar dapat mendukung terjadinya perubahan perilaku yang lebih baik bagi siswa. Untuk mencapainya pendidik dapat menggunakan berbagai sumber belajar untuk mendudukung proses terjadinya perubahan tingkah laku pada siswa. Selain itu, pendidik juga harus menggunakan strategi ataupun metode pembelajaran agar siswa 
tertarik dan mudah memahami materi yang akan diajarkan.

Sekolah dasar (SD) sebagai penggalan pertama pendidikan dasar, seyongyanya dapat membentuk landasan yang kuat untuk tingkat pendidikan selanjutnya. Dengan tujuan sekolah harus membekali lulusannya dengan kemampuan dan keterampilan dasar yang memadai, yaitu kemampuan proses strategis.

Adapun kemampuan proses strategis adalah keterampilan berbahasa. Dengan kemampuan berbahasa yang dimiliki, siswa mampu menimba berbagai pengetahuan mengapresiasi sastra, serta mengembangkan diri secara berkelanjutan. Dengan kemampuan berbahasa yang dimiliki siswa, siswa akan mampu menimba berbagai ilmu pengetahuan yang terutama dan ditujukan dalam memahami materi bahasa Indonesia, bersastra, bahasa seni dan sastra.

Dengan bahasa orang dapat: menjadi makhluk sosial berbudaya, membentuk pribadi yang baik, menjadi makhluk berpribadi, menjadi warganegara, serta untuk memahami dan berpartisipasi dalam proses pembangunan masyarakat, untuk masa sekarang dan yang akan datang. Masa mendatang kita dipacu oleh kemajuan global salah satunya yang sangat nyata bidang teknologi dan informasi yang semakin canggih dengan kemampuan membaca, menulis seiring kemajuan zaman haruslah kita kembangkan secara sungguh-sungguh, agar semua kemajuan dapat kita ikuti dengan baik, benar dan tepat guna.

Bahasa Indonesia merupakan mata pelajaran yang dipelajari di sekolah dasar mulai dari kelas 1 sampai kelas 6 . Pembelajaran di SD ini dapat dibagi menjadi pembelajaran kelas rendah dan kelas tinggi. Pembelajaran Bahasa Indonesia di kelas rendah memiliki kekhasan sendiri. Kekhasan ini tampak dari pendekatan pembelajaran yang menggunakan pendekatan tematik. Kekhasan juga tampak secara jelas dari materi bahan ajar yang diajarkan di SD kelas rendah.

Kekhasan pendekatan dan isi materi ajar di kelas rendah dibuat agar tujuan pengajaran bahasa Indonesia dapat tercapai yaitu 1) Siswa menghargai dan mengembangkan bahasa Indonesia sebagai bahasa persatuan (nasional) dan bahasa Negara; 2) Siswa memahami Bahasa Indonesia dari segi bentuk makna, dan fungsi, serta menggunakan dengan tepat dan kreatif untuk bermacam-macam tujuan, keperluan dan keadaan; 3) Siswa memiliki kemampuan menggunakan Bahasa Indonesia untuk meningkatkan kemampuan itelektual, kematangan emosional, dan kematangan sosial; 4) Siswa memiliki disiplin dalam berpikir dan berbahasa (berbicara dan menulis); 5) 
Siswa mampu menikmati dan memanfaatkan karya sastra untuk mengembangkan sastra Indonesia sebagai khazanah budaya dan intelektual manusia Indonesia.

Proses pembelajaran Bahasa Indonesia menuntut optimalisasi tidak hanya pada aspek materi, tetapi juga aspek penggunaan metode dan teknik pembelajaran di kelas. Rivers (1987) menyatakan bahwa proses belajar mengajar memerlukan interaksi yang memadai yang merupakan syarat mutlak untuk berkembangnya belajar bahasa yang optimal.

Interaksi diyakini berperan sebagai proses kognitif dalam interaksi murid dengan masukan dan murid dengan sesama (teman)nya. Oleh karena itu, murid tidak hanya sekadar menyimak masukan, tetapi berpartisipasi aktif dalam mengolah dan menegosiasikan masukan tersebut (Long, 1983). Dengan kata lain, belajar bahasa yang optimal memerlukan interaksi negosiatif yang menempatkan murid pada posisi pengolah informasi yang diperlukan melalui makna dengan guru dan sesama temannya.

Pembelajaran Bahasa Indonesia di SD dilaksanakan dalam 4 jam perminggu. Dalam satu minggu siswa hanya dua kali pertemuan, sedangkan cakupan materi pada mata pelajaran Bahasa Indonesia tidaklah sedikit sehingga guru harus mengejar waktu untuk menyelesaikan dengan tepat waktu. Hal ini yang kemudian memunculkan adanya indikasi permasalahan dalam pembelajaran. Berdasarkan hasil wawancara dengan guru kelas SD Negeri 96 Palembang, ada beberapa permasalahan yang terkait dengan pembelajaran Bahasa Indonesia pada materi mengomentari persoalan faktual.

Permasalahan dari kondisi siswa yaitu: 1) siswa merasa malas apabila diberi tugas untuk membuat karangan, 2) siswa kurang percaya diri untuk berbicara didepan kelas, 3) siswa kurang aktif ketika diminta untuk bertanya, memberikan pendapat/gagasan ataupun mendemonstrasikan, 4) siswa hanya mendengarkan guru menyampaikan materi dan menulis ketika diminta guru. Permasalahan dari kondisi guru yaitu: 1) pembelajaran masih berpusat pada guru, 2) penggunaan model atau metode yang tidak selalu diterapkan, 3) pemanfaatan media pembelajaran yang belum bervar iasi. Padahal dalam materi mengomentari berita faktual dibutuhkan siswa yang memiliki keberanian untuk berbicara di depan teman kelasnya, agar pembelajaran lebih aktif dan bermakna.

Terkait dengan permasalahan di atas, guru dan peneliti sepakat mengadakan evaluasi dan pengamatan terhadap pembelajaran pembelajaran Bahasa 
indonesia di sekolah, adapun judul penelitian ini Pembelajaran Bahasa Indonesia dan sastra (Basastra) di Sekolah Dasar.

\section{PEMBAHASAN}

\section{a. Pembelajaran Bahasa Indonesia}

Dalam pembelajaran Bahasa dan Sastra Indonesia di Sekolah Dasar, siswa diharapkan belajar bahasa Indonesia dan guru diharapkan mengajarkan bahasa Indonesia karena bagaimanapun juga guru merupakan kunci utama keberhasilan pembelajaran bahasa Indonesia di sekolah dasar. Tidak semua anak dapat berbicara bahasa Indonesia dengan baik dan benar, karena hampir setiap anak berkomunikasi menggunakan bahasa ibu sehingga tugas guru mengajarkan bahasa Indonesia agar anak dapat berkomunikasi dengan baik menggunakan bahasa nasional yaitu bahasa Indonesia.

Pada tahun 1996 UNESCO mencanangkan pilar-pilar penting dalam pendidikan, yakni bahwa pendidikan hendaknya mengembangkan kemampuan belajar untuk mengetahui (learning to know), belajar untuk melakukan sesuatu (learning to do), belajar menjadi seseorang (learning to be), dan belajar menjalani kehidupan bersama (learning to live together). Dalam konteks Indonesia, penerapan konsep pilar-pilar pendidikan ini adalah bahwa system pendidikan
Nasional berkewajiban untuk mempersiapkan seluruh warganya agar mampu berperan aktif dalam semua sector kehidupan guna mewujudkan khidupan yang cerdas, aktif, kreatif, dan mengutamakan persatuan dan kesatuan.

\section{b. Ciri-ciri jenjang pendidikan formal} SD

a. Tumbuh keimanan dan ketaqwaan terhadaap Tuhan Yang Maha Esa,

b. Tumbuh sikap beretika ( sopan santun dan beradab)

c. Tumbuh penalaran yang baik (mau belajar, ingin tahu, senang membaca, memiliki inovasi, berinsiatif dan bertanggungjawab):

d. Tumbuh kemampuan komunikasi/ soaial tertib, sadar aturan dapat bekerja sama dengan teman, dapat berkompetisi); dan

e. Tumbuh kesadaran untuk menjaga kesehatan badan. 6

\section{Pengertian Bahasa}

Bahasa merupakan kebutuhan setiap umat manusia. Bahasa juga merupakan salah satu unsur budaya dan simbol bagi manusia dalam berkomunikasi terhadap semua kebutuhan. Melalui bahasa, manusia dapat menyampaikan atau menerima berbagai pesan, baik untuk dirinya maupun untuk orang lain. Bahasa dalam lingkup yang sangat luas tidak hanya tertuju pada bahasa lisan atau bahasa tertulis. 
Bahasa merupakan alat komunikasi sosial yang berupa sistem simbol bunyi yang dihasilkan dari ucapan manusia. Manusia sebagai makhluk sosial membutuhkan sarana untuk berinteraksi dengan manusia lainnya di masyarakat. Untuk kepentingan interaksi sosial itu, maka dibutuhkan suatu wahana komunikasi yang disebut bahasa. Setiap masyarakat tentunya memiliki bahasa.

Secara sederhana, bahasa dapat diartikan sebagai suatu sistem lambang terorganisasi yang disepakati secara umum dan merupakan hasil belajar yang digunakan untuk menyajikan pengalamanpengalaman dalam suatu komunitas. Bahasa merupakan alat utama penyaluran kepercayaan, nilai, dan norma, termasuk seni dan religi.

Bahasa adalah alat untuk berinteraksi dengan orang lain dan sebagai alat bantu berpikir. Bahasa erat hubungannya dengan budaya mengingat bahasa erat kaitannya dengan pola pikir suatu masyarakat. Artinya, bahasa memegang peranan yang sangat penting di dalam proses berpikir dan kreativitas setiap individu. Bahasa bersifat simbolis, artinya suatu kata mampu melambangkan arti apapun. Melalui bahasa terjadi pewarisan budaya dari satu generasi ke generasi selanjutnya. Misalnya, seorang pelukis di pantai panjang Bengkulu membimbing muridnya cara melukis bungg Raflesia dengan menggunakan bahasa Bengkulu. Seorang guru bahasa daerah seperto bahasa kagannga di daerah Curup akan mengajarakn siswa nya menggunakan bahasa kagangga. Begitu juga, para ustads di MDA akan mengajarkan muridanya seni membaca al Quran dengan bahasa Arab dan bahasa daerah setempat.

\section{Tujuan Pengajaran}

Suatu kegiatan tentulah memiliki suatu tujuan yang hendak dicapai, dan untuk mewujudkan tujuan tersebut memerlukan pengorbanan, usaha yang maksimal dengan segala kemampuan yang ada. Keberhasilan dari tujuan yang hendak dicapai dalam suatu kegiatan tergantung dengan kesungguh-sungguhan pelaku kegiatan dalam menjalankan kegiatan tersebut untuk mencapai tujuan yang dikehendaki. Begitu juga dengan suatu pengajaran di sekolah sangat mempunyai tujuan yang akan dicapai.

Dalam dunia pendidikan pun segala kegiatan yang dilakukan pasti mempunyai suatu tujuan yakni melakukan suatu perubahan-perubahan yang pasti kearah kemajuan, kearah perbaikan. Sardima AM mengatakan bahwa tujuan dalam dunia pendidikan dapat diartikan sebagai suatu usaha untuk memberikan rumusan hasil yang diharapkan dari siswa/ subyek belajar, setelah menyelesaikan/ memperoleh pengalaman belajar. Winarno 
Surakhmad seperti yang dikutip Sardiman AM memberikan keterangan bahwa rumusan dan taraf pencapaian tujuan pengajaran adalah merupakan petujuk praktis tentang sejauh manakah interaksi edukatif itu harus dibawa untuk mencapai tujuan akhir.

Dengan demikian tujuan itu sesuatu yang diharapkan/ diinginkan dari subyek belajar, sehingga memberi arah, kemana kegiatan belajar-mengajar itu harus dibawa dan dilaksanakan. Tujuan pembelajaran harus dirumuskan karena akan membantu mempermudah guru dalam mendisain program dan kegiatan pengajaran, memudahkan pengawasan dan penilaian hasil belajar sesuai yang diharapkan dan memberikan pedoman bagi siswa dalam menyelesaikan materi dan kegiatan belajar.

\section{Kurikulum K-13}

Pengesahan kurikulum 2013 merupakan penyempurnaan dari kurikulum sebelumnya, yakni Kurikulum 2006 atau KTSP (Kurikulum Tingkat Satuan Pendidikan) telah membawa perubahan yang mendasar dalam pembelajaran Bahasa Indonesia. Pada Kurikulum 2006, mata pelajaran Bahasa Indonesia lebih mengedepankan pada keterampilan berbahasa (dan bersastra), sedangkan dalam Kurikulum 2013, Pembelajaran Bahasa Indonesia digunakan sebagai sarana untuk mengembangkan kemampuan dan keterampilan menalar. Perubahan ini terjadi dilatarbelakangi oleh kenyataan bahwa kemampuan menalar peserta didik Indonesia masih sangat rendah. Hal ini diketahui dari studi Trends in International Mathematics and Science Study (TIMSS) tahun 2011, hanya lima persen peserta didik Indonesia yang mampu memecahkan persoalan yang membutuhkan pemikiran, sedangkan sisanya 95 persen, hanya sampai pada level menengah, yaitu memecahkan persoalan yang bersifat hapalan. Ini membuktikan, bahwa pendidikan Indonesia baru berada pada tatanan konseptual. Untuk itu, pembelajaran bahasa Indonesia merupakan salah satu solusi, yaitu dengan menjadikan bahasa sebagai penghela ilmu pengetahuan dan pembelajaran berbasis teks.

$$
\text { Adanya Perubahan dalam }
$$
pembelajaran bahasa Indonesia tersebut seyogiaya diiringi dengan kompetensi guru dalam mengimplementasikan pembelajaran bahasa dengan pradigma baru yaitu pembelajaran berbasis "Teks". Untuk itu, dalam paparan ini akan menyigi Pembelajaran Bahasa Indonesia dalam Kurikulum 2013 sebagai Kajian dalam Mata Diklat Penerapan Kurikulum 2013. Dengan perubahan kurikulum pembelajaran maka impleentasi pembelajaran bahasa Indonesia berbasis teks dalam kurikulum K13. 


\section{Pembelajaran Bahasa Indonesia}

Pembelajaran bahasa Indonesia pada hakikatnya adalah membelajarkan peserta didik tentang keterampilan berbahasa Indonesia yang baik dan benar sesuai tujuan dan fungsinya. Menurut Atmazaki, mata pelajaran Bahasa Indonesia bertujuan agar peserta didik memiliki kemampuan berkomunikasi secara efektif dan efisien sesuai dengan etika yang berlaku, baik secara lisan maupun tulis, menghargai dan bangga menggunakan bahasaIndonesia sebagai bahasa persatuan dan bahasa negara, memahami bahasa Indonesia dan menggunakannya dengan tepat dan kreatif untuk berbagai tujuan, menggunakan bahasa Indonesia untuk meningkatkan kemampuan intelektual, serta kematangan emosional dan sosial, menikmati dan memanfaatkan karya sastra untuk memperluas wawasan, budi pekerti, serta meningkatkan pengetahuan dan kemampuan berbahasa, dan menghargai dan membanggakan sastra Indonesia sebagai khazanah budaya dan intelektual manusia Indonesia.

Untuk mengimplementasikan tujuan mata pelajaran Bahasa Indonesia tersebut, maka pembelajaran bahasa Indonesia dalam kurikulum 2013 disajikan dengan menggunakan pendekatan berbasis teks. Teks dapat berwujud teks tertulis maupun teks lisan. Teks merupakan ungkapan pikiran manusia yang lengkap yang di dalamnya memiliki situasi dan konteks. Dengan kata lain, belajar Bahasa Indonesia tidak sekadar memakai bahasa Indonesia sebagai alat komunikasi, tetapi perlu juga mengetahui makna atau bagaimana memilih kata yang tepat yang sesuai tatanan budaya dan masyarakat pemakainya.

Mahsun, menyatakan, dalam pembelajaran Bahasa ada dua komponen yang harus dipelajarai, yaitu masalah makna dan bentuk. Kedua unsur tersebut harus hadir secara stimulant dan keduanya harus ada. Namun pemakai bahasa harus menyadari bahwa komponen makna menjadi unsur utama dalam pembentuk bahasa, dan karena itu bahasa menjadi sarana pembentukan pikiran manusia. Untuk itu guru perlu menyadari, bahwa kemampuan berpikir yang harusnya dibentuk dalam bahasa adalah kemampuan berpikir sistematis, terkontrol, empiris, dan kritis. Secara stipulatif kemampuan berpikir tersebut disebut dengan berpikir metodologis yang hanya dapat dicapai melalui pembelajaran teks berdasarkan pendekatan ilmiah/ saintifik.

Pada kesempatan lain Mahsun, menyatakan, kehadiran konteks budaya, selain konteks situasi yang melatarbelakangi lahirnya suatu teks menunjukkan adanya kesejajaran antara 
pembelajaran berbasis teks (konsep bahasa) dengan filosofi pengembangan Kurikulum 2013. Khusus yang terkait dengan rumusan kebutuhan kompetensi peserta didik dalam bentuk kompetensi inti (KI) atas domein sikap, pengetahuan, dan keterampilan (sebagai penguatan dapat dilihat dalam Standar Isi Permen dikbud Tahun 2014).

Kompetensi inti yang menyangkut sikap, baik sikap spiritual (KI: 1 ) maupun sikap sosial (KI: 2) terkait dengan konsep kebahasaan tentang nilai, norma kultural, serta konteks sosial yang menjadi dasar terbentuknya register (bahasa sebagai teks); kompetensi inti yang menyangkut pengetahuan (KI: 3) dan keterampilan (KI: 4) terkait langsung dengan konsep kebahasaan yang berhubungan dengan proses sosial (genre) dan register (bahasa sebagai teks). Selain itu, antarkompetensi dasar (KD) yang dikelompokkan berdasarkan KI tersebut memiliki hubungan pendasaran satu sama lain. Ketercapaian KD dalam kelompok KI: 1 dan 2 ditentukan oleh ketercapaian KD dalam kelompok KI: 3 dan 4. KD dalam kelompok KI: 1 dan 2 bukan untuk diajarkan melainkan implikasi dari ketercapaian KD dalam kelompok KI: 3 dan 4.13.

Pencapaian kompetensi tersebut berkaitan erat dengan proses pembelajaran yang dilaksanakan. Untuk itu, guru harus merencanakan pembelajaran sesuai tuntutan kurikulum dengan menggunakan pendekatan saintifik dan model pembelajaran yang mendorong kemampuan peserta didik untuk melakukan penyingkapan/penelitian, serta dapat menghasilkan karya kontekstual, baik individual maupun kelompok.

Dengan memahami keterkaitan masing-masing kompetensi dalam pembelajaran, khusunya pembelajaran bahasa Indonesia dengan pembelajaran berbasis teks akan mampu mengembangkan kemampuan berpikir peserta didik secara kreatif dan kritis. Di samping itu, pembelajaran Bahasa Indonesia dapat berperan sebagai penghela dan pengintegrasi ilmu lain.

Untuk meningkatkan kualitas pembelajaran yang bermuara pada hasil belajar yang lebih baik, Jerry Aldridge dan Renitta Goldman merekomendasikan beberapa hal yang harus dilakukan oleh guru. Pertama, guru harus mampu menciptakan situasi kelas yang tenang, bersih, tidak stress, dan sangat mendukung untuk pelaksanaan proses pembelajaran. Kedua, guru harus menyediakan peluang bagi anak didik untuk mengakses seluruh bahan dan sumber informasi untuk belajar.

Ketiga, Gunakan model cooperative learning melalui diskusi dalam kelompok-kelompok kecil, debat, atau mendemonstrasikan (demonstrasi). 
Keempat, hubungkan informasi baru pada sesuatu yang sudah diketahui oleh anak didik, sehingga mudah untuk mereka pahami. Kelima, dorong anak didik untuk mengerjakan tugas-tugas penulisan makalahnya dengan melakukan kajian dan penelusuran hal-hal baru dalam kajian yang mendalam, Keenam, guru harus memiliki catatan-catatan kemajuan dari semua proses pembelajaran anak didik, termasuk tugas-tugas individu dan kelompok mereka dalam bentuk pembahasan soal-soal.

\section{KESIMPULAN}

Di sekolah dasar pembelajaran bahasa dan sastra Indonesia lebih diarahkan pada kompetensi siswa untuk berbahasa dan berapresiasi sastra. Pelaksanaannya, pembelajaran sastra dan bahasa dilaksanakan secara terintegrasi. Sedangkan pengajaran sastra, ditujukan untuk meningkatkan kemampuan siswa dalam menikmati, menghayati, dan memahami karya sastra. Pengetahuan tentang sastra hanyalah sebagai penunjang dalam mengapresiasi.

Untuk meningkatkan kualitas pembelajaran yang bermuara pada hasil belajar yang lebih baik, Jerry Aldridge dan Renitta Goldman merekomendasikan beberapa hal yang harus dilakukan oleh guru. Pertama, guru hars mampu menciptakan situasi kelas yang tenang, bersih, tidak stress, dan sangat mendukung untuk pelaksanaan proses pembelajaran. Kedua, guru harus menyediakan peluang bagi anak didik untuk mengakses seluruh bahan dan sumber informasi untuk belajar. Ketiga, Gunakan model cooperative learning melalui diskusi dalam kelompokkelompok kecil, debat, atau mendemonstrasikan (demonstrasi).

Keempat, hubungkan informasi baru pada sesuatu yang sudah diketahui oleh anak didik, sehingga mudah untuk mereka pahami. Kelima, dorong anak didik untuk mengerjakan tugas-tugas penulisan makalahnya dengan melakukan kajian dan penelusuran hal-hal baru dalam kajian yang mendalam, Keenam, guru harus memiliki catatan-catatan kemajuan dari semua proses pembelajaran anak didik, termasuk tugas-tugas individu dan kelompok mereka dalam bentuk pembahasan soal-soal.

\section{DAFTAR PUSTAKA}

Ali Muhammad, Ilmu dan Aplikasi Pendidikan I. (Bandung: Angkasa 2009: 33).

Atmazaki. 2013. Mengungkap Masa Depan: Inovasi Pembelajaran Bahasa Indonesia dalam Konteks Pengembangan Karakter Cerdas. Makalah. Padang: UNP.

Fasli Jalil, Dedi Supriadi, Reformasi Pendidikan Dalam Konteks Otonomi Daerah, (Yogyakarta 
Adicita Karya Nusa, 2000). Kartadinata Sunaryo. Panduan Pengajar Buku Inovasi Pendidikan, (Jakarta,. Depdikbud. 2000).

Long, M.H. 1983. Does Second Language Instruction Make a Difference? A Review of the Research. TESOL Quarterly 17.

Mahsun. 2014. Teks Pembelajaran Bahasa Indonesia Kurikulum 2013. Jakarta: Raja Grafindo Persada.

Mulyasa E. Pengembangan dan Implementasi Kurikulum 2013. ( Bandung: PT. Remaja Rosdakarya, 2013 ).

Nasution, S., 1999, Kurikulum dan Pengajaran, Jakarta: Bumi Aksara, cet-ke-3
Nurgiyantoro, Burhan. 2001. Penilaian dalam Pengajaran Bahasa dan Sastra. Edisi Ketiga. Yogyakarta: BPFE.

Sardiman A.M,. Interaksi \& Motivasi Belajar Mengajar. (Jakarta: Rajawali Pers. 2000 ).

Slamet. Dasar-dasar Pembelajaran Bahasa dan Sastra Indonesia di Sekolah Dasar (Jakarat: Lembaga Pengembangan Pendidikan (LPP) UNS dan UPT Penerbitan dan Percetakan UNS (UNS Pres.: 2007

Sukardjo dan Ukim Komarudin, Landasan Pendidikan, (Depok: PT Raja Grafindo Persada, 2012). 